\title{
A prospective study of occupational physical activity and breast cancer risk
}

\author{
Christine C. Ekenga ${ }^{1}$, Christine G. Parks ${ }^{2}$, and Dale P. Sandler ${ }^{2}$ \\ ${ }^{1}$ Division of Public Health Sciences, Department of Surgery, Washington University School of \\ Medicine, Saint Louis, MO \\ 2Epidemiology Branch, National Institute of Environmental Health Sciences, National Institutes of \\ Health, Department of Health and Human Services, Research Triangle Park, NC
}

\begin{abstract}
Purpose-Physical activity has been associated with reduced breast cancer risk, but studies of occupational activity have produced inconsistent results. The purpose of this study was to evaluate the relationship between occupational physical activity and breast cancer in a prospective study of women with a family history of breast cancer.
\end{abstract}

Methods-We studied breast cancer risk in 47,649 Sister Study participants with an occupational history. Information on occupational activity and breast cancer risk factors was collected during baseline interviews (2004-2009). Physical activity at each job was self-reported and categorized as mostly sitting, sitting and standing equally, mostly standing, and active. Multivariable Cox proportional hazards regression was used to evaluate associations between lifetime occupational activity and incident breast cancer, after adjusting for established risk factors and recreational activity.

Results-During follow-up, a total of 1,798 breast cancer diagnoses were reported. Compared with women who did not spend any time in active jobs, women who spent a high proportion ( $\geq 75 \%)$ of their working years in active jobs had a reduced risk of breast cancer (HR $=0.72 ; 95 \%$ $\mathrm{CI}=0.52-0.98)$. Associations were strongest among overweight $(\mathrm{HR}=0.64 ; 95 \% \mathrm{CI}=0.42-0.98)$ and postmenopausal $(\mathrm{HR}=0.67 ; 95 \% \mathrm{CI}=0.45-0.98)$ women.

Conclusions-Occupational activity was associated with a reduced risk of breast cancer. Occupational activity is a domain of physical activity that should be further examined in studies of postmenopausal breast cancer risk. Additional research is necessary to better understand the mechanisms between occupational activity, body size, and breast cancer.

\section{Keywords}

Breast Cancer; Cohort; Physical Activity; Workplace; Women

Contact: Dale P. Sandler, PhD, Epidemiology Branch, Division of Intramural Research, National Institute of Environmental Health Sciences, Research Triangle Park, NC 27709, dale.sandler@nih.gov.

Conflict of Interest: The authors declare that they have no conflict of interest. 


\section{Introduction}

Physical activity is a modifiable risk factor for breast cancer. An inverse association between recreational physical activity and breast cancer has been well established in epidemiologic studies [1,2]. It is not clear, however, if occupational physical activity reduces the risk of breast cancer. Epidemiologic case-control studies have produced inconsistent results. Some have reported that high levels of occupational physical activity are associated with a reduced risk of breast cancer [3-19], whereas others have found an opposite or non-significant effect [20-28]. Few prospective studies have evaluated the association between occupational physical activity and breast cancer risk. Although a recent meta-analysis of seven studies reported a statistically significant inverse relationship between occupational activity and breast cancer risk [29], not all prospective studies have shown such an association [30-34].

The inconsistent results of previous studies may be due to variations in occupational physical activity assessment. The majority of studies of occupational activity and breast cancer risk have examined activity at one defined time period in an individual's occupational history. These studies have often characterized activity levels using job title information, which does not account for the variability in activity among women with the same job title or the variability in activity within a job title that may be associated with age or time period. Few prospective studies have examined the relationship between total lifetime occupational activity and breast cancer risk [30,35], and a limited number have evaluated breast cancer risk by menopausal status [36] or tumor subtypes [32,37], factors that may relate to disease etiology and prognosis. Therefore, in the present study, we examined lifetime occupational physical activity in relation to the incidence of breast cancer overall, by menopausal status and by estrogen receptor status among women in the Sister Study.

\section{Methods}

\section{Study Population}

We analyzed data from the Sister Study, a prospective cohort study of genetic and environmental risk factors for breast cancer (www.sisterstudy.niehs.nih.gov). Briefly, between 2004 and 2009, the Sister Study enrolled 50,884 breast cancer-free women from the United States and Puerto Rico, aged 30-74 years with a sister who had breast cancer. Written informed consent was obtained and questionnaire data on potential risk factors for breast cancer was collected during baseline activities. The Internal Review Boards at the National Institute of Environmental Health Sciences and Copernicus Group approved the study.

For the purpose of this analysis, we excluded women who were diagnosed with breast cancer before baseline activities were completed $(n=94)$, a vanguard group of women who had completed a non-comparable version of the occupational questionnaire $(n=3,129)$, and women without an occupational history $(\mathrm{n}=12)$. The analytical cohort was made up of 47,649 women who reported having worked at least one job outside of the home. 


\section{Occupational Physical Activity}

At enrollment, participants completed a computer-assisted telephone interview in which they reported detailed information for each job held after the age of 18 years, including hours per week and total number of years worked. For each job, participants also were asked "which of the following best describes your usual physical activity on the job?" Possible responses were: (1) mostly sitting, with some standing and/or walking, (2) sitting and standing equally, (3) mostly standing with some walking, (4) continuous walking or other movements that increase your heart rate slightly, (5) heavy manual labor that causes sweating or increases your heart substantially, and (6) sporadic heavy manual labor. Because of small numbers, the latter three activity levels were collapsed to create one category (active). Thus, we present four response categories of physical activity intensity for each job: mostly sitting, sitting and standing equally, mostly standing, and active.

\section{Follow-Up}

Participants were followed from baseline until breast cancer diagnosis, death, or end of follow-up. Participants completed brief annual health update questionnaires and more comprehensive follow-up questionnaires every two (first follow-up) or three (second followup) years. Throughout follow-up, a response rate above $92 \%$ had been achieved. These selfor telephone-administered questionnaires were used to identify incident breast cancer diagnoses. When a participant reported breast cancer, we requested permission to obtain medical records from her physician. Medical records and pathology reports have been obtained from $81 \%$ of participants with self-reported breast cancer to date. Because of high agreement between self-reports and medical records (99.5\%), we included self-reported cases in this analysis.

\section{Statistical Analysis}

Multivariable-adjusted hazard ratios (HR) and 95\% confidence intervals (CI), with age as the timescale, were used to evaluate the association between occupational physical activity and breast cancer. Confounders that were associated with both occupational activity and breast cancer, but not in the causal pathway, were identified using a directed acyclic graph (DAG) and change-in-estimate approach [38]. Multivariable models were adjusted for race/ ethnicity (non-Hispanic White, non-Hispanic Black, Hispanic, other), education level (<high school graduate/GED, high school graduate/ GED, some college, college/post graduate), income ( $<\$ 50,000, \$ 50,000$ to $<\$ 100,000, \$ 100,000)$, parity (nulliparous, $1,2,3+$ births), age at first term pregnancy ( $<21,21$ to $<24,24$ to $<28,28+$ years), menopause status (premenopausal, postmenopausal), age at menopause ( $<45,45$ to 49,50 to $54,55+$ years), body mass index $\left(<25,20-<30,30+\mathrm{kgm}^{-2}\right)$, work at night (ever or never), and recreational physical activity in quartiles $(<27.05,27.05-<44.40,44.40-<67.16,67.16+$ Metabolic equivalent task (MET)-hours per week; weekly energy expenditures were determined using MET values for each participant-reported sports and exercise activity [39]). Additional adjustment for hormonal birth control use, hormone therapy use, marital status, alcohol consumption, smoking status, and chronic disease history did not significantly impact risk estimates (results not shown). 
Two approaches were used to explore the relationship between occupational physical activity and breast cancer. The first set of analyses estimated the risk for breast cancer (overall, premenopausal, and postmenopausal) associated with the following measures of lifetime occupational activity: (a) employment in an active job (ever/never), (b) total years of employment in active jobs, and (c) the proportion of employment years in active jobs. Hazard ratios for breast cancer were also estimated for estrogen receptor-positive and estrogen receptor-negative tumors separately.

A second set of analyses evaluated breast cancer risk in relation to the intensity of occupational physical activity in the workplace (active, mostly standing, sitting and standing equally, mostly sitting). Among women currently employed at baseline, we examined breast cancer risk as a function of the physical activity level at the longest held job (longest held $j o b$ ) and as a function of the physical activity level at the job currently held at baseline (current job). Statistical analysis was done with SAS statistical software package (version 9.4, SAS Institute, Cary, NC, USA).

\section{Results}

Of the 47,649 women who reported work outside of the home, 2,276 had missing activity or covariate data. This resulted in 45,373 Sister Study participants available for analyses. Characteristics of the participants by lifetime occupational physical activity status are presented in Table 1. Approximately $26 \%$ of the study population reported at least one active job in their lifetime, and the mean number of years worked in an active jobs was 10.5 $( \pm 8.6)$ years. The most commonly reported active jobs were Registered Nurses, Maids and Housekeeping Cleaners, and Retail Salespersons. At baseline, active women were more likely to be younger than women who never worked in an active job. Compared with never active women, active women reported lower levels of educational attainment and lower incomes. A higher proportion of active women (33\%) were obese at baseline than never active women (29\%), and active women were also more likely to have higher levels of recreational activity at baseline. More than half (51\%) of active women worked a night job, while only $22 \%$ of never active women reported working at night.

A total of 1,798 cases of breast cancer were reported during follow-up ( $4.7 \pm 1.6$ years). Table 2 shows the risk for breast cancer associated with lifetime occupational physical activity. Among all study participants, women who reported at least one active job in their lifetime had a non-significant reduced risk of breast cancer (HR $=0.91,95 \%$ CI: 0.80, 1.03) compared with women who did not report active work. There was no association between the duration of years of active work and breast cancer $\left(P_{\text {trend }}=0.31\right)$. When compared with women who had never worked in an active job, women who spent at least three-quarters of their work years in active jobs had a $28 \%$ decreased risk of breast cancer ( $\mathrm{HR}=0.72,95 \%$ CI: $0.52,0.98)$. Adjusting for total work years did not significantly change risk estimates.

Body mass index modified the relation between occupational physical activity and incident breast cancer (interaction P-values $<0.10$ ). Risk reductions were stronger among overweight women (Table 2). The association between the proportion of years in active work and breast cancer was not significant in underweight and normal weight women. However, among 
those with a body mass index equal to or above 25 , three-quarters or more of active work was significantly associated with a $36 \%$ reduced risk of breast cancer $(\mathrm{HR}=0.64,95 \% \mathrm{CI}$ : $0.42,0.98)$. Risk reductions were similar for women with waist circumferences greater than 80 centimeters ( $\mathrm{HR}=0.64,95 \% \mathrm{CI}: 0.42,0.98)$, and women with waist-to-hip ratios equal to or above $0.8(\mathrm{HR}=0.54,95 \% \mathrm{CI}: 0.33,0.89)$ (Table 3$)$.

A total of 1,363 (76\%) women were postmenopausal at the time of diagnosis (Table 4). After adjusting for covariates, women who reported a history of at least one active job had a borderline reduced risk of postmenopausal breast cancer ( $\mathrm{HR}=0.86,95 \% \mathrm{CI}: 0.74,1.00$ ) compared with women who never reported an active job. No significant trends were observed for the duration of employment $\left(\mathrm{P}_{\text {trend }}=0.34\right)$ or the proportion of work years $\left(\mathrm{P}_{\text {trend }}=0.74\right)$ in active jobs, however women who reported three-quarters or more of work years in active jobs had a decreased risk of postmenopausal breast cancer ( $\mathrm{HR}=0.67,95 \%$ CI: $0.45,0.98)$. Postmenopausal women who were overweight (BMI 225$)$ also had a reduced, albeit non-significant, risk of breast cancer (HR $=0.63,95 \% \mathrm{CI}$ : $0.38,1.03$ ) (data not shown). Among premenopausal women, there were no significant reductions in risk associated with occupational activity.

Table 5 displays results by estrogen receptor status. Of the 1,571 cases with known estrogen receptor status, 1300 (83\%) were estrogen receptor-positive and 271 (17\%) were estrogen receptor-negative. Risk reductions were observed only for estrogen receptor-positive tumors. Among postmenopausal, overweight (BMI 225 ) women, there was a $49 \%$ decrease in estrogen receptor-positive tumor risk ( $\mathrm{HR}=0.51,95 \% \mathrm{CI}: 0.30,0.91)$ (data not shown).

Approximately $66 \%(n=31,289)$ of the study population was currently employed at baseline. In this subgroup, the relationship between breast cancer risk and intensity of occupational physical activity at the longest held job and the job currently held at the baseline interview was evaluated (Table 6). For the longest held job, $11 \%$ of the study population reported active work, $19 \%$ reported mostly standing, $22 \%$ reported sitting and standing equally at work and $48 \%$ reported mostly sitting in the workplace (data not shown). Compared with women who reported mostly sitting, there were no significant associations between active work ( $\mathrm{HR}=0.84,95 \%$ CI: $0.66,1.08)$, mostly standing at work ( $\mathrm{HR}=0.96$, $95 \%$ CI: $0.80,1.15)$, or sitting and standing equally at work (HR $=1.05,95 \%$ CI: $0.89,1.23)$ and breast cancer risk.

Among women currently employed at baseline, $9 \%$ reported active work, $17 \%$ reported mostly standing, $21 \%$ reported sitting and standing equally, and 53\% reported mostly sitting in their current jobs (data not shown). While being active (HR $=0.75,95 \% \mathrm{CI}: 0.58,0.96)$ in the current job was associated with a reduced breast cancer, mostly standing (HR $=0.93$, $95 \%$ CI: $0.78,1.11)$ and sitting and standing equally (HR $=0.87,95 \%$ CI: $0.74,1.02)$ were not significantly associated with a reduced breast cancer risk (Table 4). Risk reductions were strongest among women with less than 5 years of work in their current position, with active work associated with a $46 \%(\mathrm{HR}=0.54,95 \% \mathrm{CI}: 0.34,0.86)$ decrease, and sitting and standing equally associated with a $31 \%(\mathrm{HR}=0.69,95 \%$ CI: $0.53,0.91)$ decrease in risk (Supplemental Table I). 


\section{Discussion}

We observed an overall reduced risk of breast cancer of borderline significance in women who reported having at least one active job in their lifetime. Women with three-quarters or more of their occupational history spent in active jobs had a significant $28 \%$ reduced risk of breast cancer, even after adjusting for recreational physical activity. Breast cancer risk varied by body mass index, with the inverse association between occupational activity and breast cancer risk more pronounced in overweight women. Analysis by menopausal status showed that an occupational history of three-quarters or more of work years in active jobs was associated with a significantly decreased risk of postmenopausal breast cancer, but not premenopausal breast cancer. We did not observe any dose-response effects between duration of active work and breast cancer risk.

The Sister Study provided a unique opportunity to examine breast cancer risk in a higher risk population, women with a family history of breast cancer. The inverse association between physical activity and breast cancer risk has generally been reported to be stronger among women without a family history [40]. Studies that evaluate the potentially modifying effect of family history on occupational activity and breast cancer have been rare. A population-based, case-control study of Netherlands residents did not observe any differences in breast cancer risk between women with a family history of breast cancer and women without a family history [23]. To the best of our knowledge, our study is the first to report significant associations between occupational physical activity and reduced breast cancer risk among women with a family history of breast cancer.

Our findings for high levels of occupational activity are consistent with previous casecontrol and cohort studies of lifetime occupational activity and breast cancer risk in a variety of populations [29,40,1]. Self-reported standing or walking was inversely associated $(\mathrm{p}<0.01)$ with breast cancer risk in a Chinese study of 1,459 cases and 1,556 controls [9]. A population-based Polish study with 2,176 cases and 2,326 controls found that heavy physical work, defined as the highest quartile of MET-hrs/week among the study population, was associated with a $40 \%$ reduced risk of breast cancer [15], and in a case-control study of 1,572 African women, a significant inverse trend $(\mathrm{p}<0.0001)$ between increasing categories of occupational MET-hrs/day and breast cancer risk was observed [19].

In our study, lifetime (ever/never) physical activity was associated with a risk reduction $(10 \%)$ that was similar to the results of a recent meta-analysis of prospective studies consisting of a total of 28,368 breast cancer cases $(R R=0.90)$ [29]. The analysis included a Chinese cohort study of 73,049 women with 717 cases of breast cancer diagnosed during 13 years of follow-up. Chinese women in the highest quartile of occupational energy had a significantly reduced risk $\left(0.73, \mathrm{P}_{\text {trend }}=0.04\right)$ of breast cancer compared with women who did not spend time in a high energy expenditure job [41]. A Finnish cancer registry study, with17,986 incident breast cancer cases and 24 years of follow-up, reported a significantly reduced incidence ratio $(S I R=0.79)$ for women who reported performing heavy tasks for most of the workday [42], and higher self-reported levels of activity was associated with a reduced risk $(\mathrm{p}=0.004)$ of breast cancer in a Norwegian study of 25,624 women with 14 years of follow-up [43]. 
Our study adds to the current literature by examining the association between occupational activity and breast cancer in several subgroups of women. Similar to results for studies of leisure-time physical activity [29,40,1], we found that the risk reductions associated with occupational activity were stronger among postmenopausal women. We know of only one other prospective study that evaluated the relationship between occupational activity and breast cancer risk by menopausal status. The multinational European Prospective Investigation into Cancer and Nutrition (EPIC) reported that the association between occupational activity and overall breast cancer risk did not differ by menopausal status [36]. However, when results were stratified by age at diagnosis (age $<50$ years versus age $\geq 50$ years), inverse risks for invasive [32] and in situ [44] tumors were stronger, but not significant, among women diagnosed at age 50 or older. The EPIC study is also the only other prospective cohort that has evaluated breast cancer risk by body mass index. There were no significant differences in the association between self-reported occupational activity and breast cancer risk among BMI subgroups in the EPIC cohort [44].

The biological mechanisms by which physical activity might influence breast cancer risk have not been well characterized. Potential mechanisms include reduced adiposity, reduced levels of estrogen, reduced inflammation, changes in insulin-like and other growth factors, and altered immune function $[45,40,46]$. In our study, women who worked in active jobs for more than three-quarters of their occupational history had a significantly reduced risk of breast cancer, and overweight women had a $46 \%$ risk reduction associated with the highest proportion of active work. Obesity has been associated with elevated levels of estradiol and reduced levels of sex hormone-binding globulin [47,48], a protein that binds estrogens and androgens and reduces the bioavailability of estrogen; however, several studies have shown that, even after adjusting for circulating estrogens, the association between body mass and postmenopausal breast cancer remains significant [49,50]. In lieu of the increased circulation and bioavailability of estrogens as a potential mechanism for breast cancer in overweight women, our findings indicate that physical activity may influence breast cancer risk through factors other than reduced adiposity.

Our physical activity measures are potential study limitations. Although questionnaires with work index/activity scores (i.e. sitting, standing, walking, heavy labor) have been shown to be reliable [51] and valid [52] instruments for physical activity assessment, occupational activity was self-reported, and there were no data available on the intensity, frequency or duration of activity in each job. In contrast to most previous studies of occupational activity [40], there was no dose-response relationship between occupational activity and breast cancer risk. This difference could be due to imprecise estimates of occupational energy expenditure. For leisure-time activity, we used a validated series of activity questions [39] to calculate total weekly energy expenditures in metabolic equivalents-hours (MET-hr/wk). We did not collect information on leisure-time physical activity before the baseline assessment period other than during childhood. As a result, we were limited in our ability to assess the impact of total lifetime leisure-time activity on occupational activity-related breast cancer risk.

High levels of occupational activity may be associated with healthy behaviors and preventive factors that reduce breast cancer risk. However, after adjusting for factors such as 
caloric intake, recent leisure-time activity, and adult weight change, the association between high lifetime occupational activity and reduced breast cancer risk remained significant. Furthermore, after examining self-reported data on workplace use of chemicals such as pesticides and solvents (unpublished Sister Study data), we observed that occupational exposure to potentially carcinogenic agents was not associated with occupational physical activity among Sister Study women. Thus, unmeasured lifestyle confounders are unlikely to account for the observed reductions in breast cancer risk.

A strength of our analysis is that the Sister Study collected data on physical activity at each job reported by a participant. This detailed information allowed us to examine breast cancer risk associated with several metrics of activity and not limit our investigation to physical activity at just one job or at just one point in time. For example, when we excluded women who were not in the workforce at baseline, we found that the risk reduction associated with active work in their longest-held job was not significant. In contrast, when we examined the relationship between occupational activity at their current job and breast cancer risk, we observed a much stronger risk reduction in breast cancer risk for women who were active, suggesting that recent activity in the workplace may have more influence on breast cancer risk than past activities. The strongest reductions were among women in active jobs for less than five years, and, although we do not have an explanation for this inverse dose-effect, we cannot exclude the potential for misclassification associated with poor recall or changes in work activities that may have occurred over time.

Additional strengths of our study include the large number of participants and the detailed data available on established risk factors for breast cancer, including reproductive and lifestyle factors. We were able to evaluate breast cancer risk in several subgroups such as menopausal status and body mass index categories. Finally, the prospective design of our study minimized the biases associated with participant self-reporting that often occurs in retrospective and case- control studies.

Our findings suggest that high levels of occupational activity may reduce the risk of breast cancer in overweight women and in postmenopausal women. Given the fact that obesity influences both the development and progression of breast cancer in older women, further investigations, with more detailed measures of physical activity, are necessary to clarify the manner in which occupational activity and body size influence breast cancer risk.

\section{Acknowledgments}

The authors would like to thank Drs Matthew Longnecker and Anne Marie Jukic for their helpful comments.

Funding: This research was supported by the Intramural Research Program of the NIH, National Institute of Environmental Health Sciences (Z01-ES-044005).

\section{References}

1. Monninkhof EM, Elias SG, Vlems FA, van der Tweel I, Schuit AJ, Voskuil DW, van Leeuwen FE. Tfpac. Physical activity and breast cancer - A systematic review. Epidemiology. 2007; 18(1):137157.10.1097/01.ede.0000251167.75581.98 [PubMed: 17130685] 
2. Lynch, B.; Neilson, H.; Friedenreich, C. Physical Activity and Breast Cancer Prevention. In: Courneya, KS.; Friedenreich, CM., editors. Physical Activity and Cancer, vol 186 Recent Results in Cancer Research. Springer Berlin; Heidelberg: 2011. p. 13-42.

3. Davanzo B, Nanni O, LaVecchia C, Franceschi S, Negri E, Giacosa A, Conti E, Montella M, Talamini R, Decarli A. Physical activity and breast cancer risk. Cancer Epidemiology Biomarkers \& Prevention. 1996; 5(3):155-160.

4. Coogan PF, Newcomb PA, Clapp RW, TrenthamDietz A, Baron JA, Longnecker MP. Physical activity in usual occupation and risk of breast cancer (United States). Cancer Causes \& Control. 1997; 8(4):626-631.10.1023/a:1018402615206 [PubMed: 9242479]

5. Mezzetti M, La Vecchia C, Decarli A, Boyle P, Talamini R, Franceschi S. Population attributable risk for breast cancer: diet, nutrition, and physical exercise. J Natl Cancer Inst. 1998; 90(5):389_ 394. [PubMed: 9498489]

6. Levi F, Pasche C, Lucchini F, La Vecchia C. Occupational and leisure time physical activity and the risk of breast cancer. European Journal of Cancer. 1999; 35(5):775-778.10.1016/ s0959-8049(99)00051-9 [PubMed: 10505038]

7. Moradi T, Nyren O, Zack M, Magnusson C, Persson I, Adami HO. Breast cancer risk and lifetime leisure-time and occupational physical activity (Sweden). Cancer Causes \& Control. 2000; 11(6): 523-531.10.1023/a:1008900512471 [PubMed: 10880034]

8. Friedenreich CM, Courneya KS, Bryant HE. Influence of physical activity in different age and life periods on the risk of breast cancer. Epidemiology. 2001; 12(6):604-612. [PubMed: 11679785]

9. Matthews CE, Shu XO, Jin F, Dai Q, Hebert JR, Ruan ZX, Gao YT, Zheng W. Lifetime physical activity and breast cancer risk in the Shanghai Breast Cancer Study. British Journal of Cancer. 2001; 84(7):994-1001.10.1054/bjoc.2000.1671 [PubMed: 11286483]

10. John EM, Horn-Ross PL, Koo J. Lifetime physical activity and breast cancer risk in a multiethnic population: The San Francisco Bay area breast cancer study. Cancer Epidemiology Biomarkers \& Prevention. 2003; 12(11):1143-1152.

11. Kruk J. Lifetime physical activity and the risk of breast cancer: A case-control study. Cancer Detection and Prevention. 2007; 31(1):18-28. doi: http://dx.doi.org/10.1016/j.cdp.2006.12.003. [PubMed: 17296272]

12. Sprague BL, Trentham-Dietz A, Newcomb PA, Titus-Ernstoff L, Hampton JM, Egan KM. Lifetime recreational and occupational physical activity and risk of in situ and invasive breast cancer. Cancer Epidemiology Biomarkers \& Prevention. 2007; 16(2):236243.10.1158/1055-9965.epi-06-0713

13. Kruk J, Aboul-Enein HY. Occupational physical activity and the risk of breast cancer. Cancer Detection and Prevention. 2003; 27(3):187-192.10.1016/s0361-090x(03)00032-1 [PubMed: 12787725]

14. Shin A, Matthews CE, Shu XO, Gao YT, Lu W, Gu K, Zheng W. Joint effects of body size, energy intake, and physical activity on breast cancer risk. Breast Cancer Res Treat. 2009; 113(1):153161.10.1007/s10549-008-9903-x [PubMed: 18228135]

15. Peplonska B, Lissowska J, Hartman TJ, Szeszenia-Dabrowska N, Blair A, Zatonski W, Sherman ME, Garcia-Closas M, Brinton LA. Adulthood Lifetime Physical Activity and Breast Cancer. Epidemiology. 2008; 19(2):226-236. 210. doi:1097/EDE.1090b1013e3181633bfb. [PubMed: 18277160]

16. Kruk J. Lifetime Occupational Physical Activity and the Risk of Breast Cancer: a Case-control Study. Asian Pacific Journal of Cancer Prevention. 2009; 10(3):443-448. [PubMed: 19640188]

17. Kobayashi L, Janssen I, Richardson H, Lai A, Spinelli J, Aronson K. Moderate-to-vigorous intensity physical activity across the life course and risk of pre- and post-menopausal breast cancer. Breast Cancer Research and Treatment. 2013; 139(3):851-861.10.1007/ s10549-013-2596-9 [PubMed: 23771716]

18. Ángeles-Llerenas A, Ortega-Olvera C, Pérez-Rodríguez E, Esparza-Cano J, Lazcano-Ponce E, Romieu I, Torres-Mejía G. Moderate physical activity and breast cancer risk: the effect of menopausal status. Cancer Causes \& Control. 2010; 21(4):577-586.10.1007/s10552-009-9487-8 [PubMed: 20084545] 
19. Hou N, Ndom P, Jombwe J, Ogundiran TO, Ademola A, Morhason-Bello I, Ojengbede O, Gakwaya A, Huo D. An Epidemiologic Investigation of Physical Activity and Breast Cancer Risk in Africa. Cancer Epidemiology Biomarkers \& Prevention. 201410.1158/1055-9965.epi-14-0675

20. Dosemeci M, Hayes RB, Vetter R, Hoover RN, Tucker M, Engin K, Unsal M, Blair A. Occupational physical-activty, socioeconomic status, and risks of 15 cancer sites in Turkey. Cancer Causes \& Control. 1993; 4(4):313-321.10.1007/bf00051333 [PubMed: 8347780]

21. Ueji M, Ueno E, Osei-Hyiaman D, Takahashi H, Kano K. Physical activity and the risk of breast cancer: a case-control study of Japanese women. Journal of epidemiology / Japan Epidemiological Association. 1998; 8(2):116-122. [PubMed: 9673081]

22. Aschengrau A, Coogan PF, Quinn MM, Cashins LJ. Occupational exposure to estrogenic chemicals and the occurrence of breast cancer: An exploratory analysis. American Journal of Industrial Medicine. 1998; 34(1):6-14.10.1002/(sici)1097-0274(199807)34:1<6: :aidajim2>3.0.co;2-x [PubMed: 9617382]

23. Verloop J, Rookus MA, van der Kooy K, van Leeuwen FE. Physical activity and breast cancer risk in women aged 20-54 years. J Natl Cancer Inst. 2000; 92(2):128-135. [PubMed: 10639514]

24. Steindorf K, Schmidt M, Kropp S, Chang-Claude J. Case-control study of physical activity and breast cancer risk among premenopausal women in Germany. Am J Epidemiol. 2003; 157(2):121130. [PubMed: 12522019]

25. Yang DY, Bernstein L, Wu AH. Physical activity and breast cancer risk among Asian-American women in Los Angeles - A case-control study. Cancer. 2003; 97(10):2565-2575.10.1002/cncr. 11364 [PubMed: 12733156]

26. Dorn J, Vena J, Brasure J, Freudenheim J, Graham S. Lifetime physical activity and breast cancer risk in pre- and postmenopausal women. Medicine and Science in Sports and Exercise. 2003; 35(2):278-285.10.1249/01.mss.0000048835.59454.8d [PubMed: 12569217]

27. Rosato V, Bertuccio P, Bosetti C, Negri E, Edefonti V, Ferraroni M, Decarli A, Talamini R, Dal Maso L, Falcini F, Montella M, Franceschi S, La Vecchia C. Nutritional factors, physical activity, and breast cancer by hormonal receptor status. Breast. 2013; 22(5):887-893.10.1016/j.breast. 2013.04.004 [PubMed: 23643804]

28. Si S, Boyle T, Heyworth J, Glass DC, Saunders C, Fritschi L. Lifetime physical activity and risk of breast cancer in pre-and post-menopausal women. Breast Cancer Res Treat. 2015; 152(2):449462.10.1007/s10549-015-3489-x [PubMed: 26126973]

29. Wu Y, Zhang D, Kang S. Physical activity and risk of breast cancer: a meta-analysis of prospective studies. Breast cancer research and treatment. 2013; 137(3):869-882.10.1007/s10549-012-2396-7 [PubMed: 23274845]

30. Moradi T, Adami HO, Ekbom A, Wedren S, Terry P, Floderus B, Lichtenstein P. Physical activity and risk for breast cancer a prospective cohort study among Swedish twins. International Journal of Cancer. 2002; 100(1):76-81.10.1002/ijc.10447

31. Lahmann PH, Friedenreich C, Schuit AJ, Salvini S, Allen NE, Key TJ, Khaw KT, Bingham S, Peeters PHM, Monninkhof E, Bueno-De-Mesquita HB, Wirfaelt E, Manjer J, Gonzales CA, Ardanaz E, Amiano P, Quiros JR, Navarro C, Martinez C, Berrino F, Palli D, Tumino R, Panico S, Vineis P, Trichopoulou A, Bamia C, Trichopoulos D, Boeing H, Schulz M, Linseisen J, ChangClaude J, Chapelon FC, Fournier A, Boutron-Ruault MC, Tjonneland A, Johnson NF, Overvad K, Kaaks R, Riboli E. Physical activity and breast cancer risk: The European prospective investigation into cancer and nutrition. Cancer Epidemiology Biomarkers \& Prevention. 2007; 16(1):36-42.10.1158/1055-9965.epi-06-0582

32. Steindorf K, Ritte R, Eomois PP, Lukanova A, Tjonneland A, Johnsen NF, Overvad K, Ostergaard JN, Clavel-Chapelon F, Fournier A, Dossus L, Teucher B, Rohrmann S, Boeing H, Wientzek A, Trichopoulou A, Karapetyan T, Trichopoulos D, Masala G, Berrino F, Mattiello A, Tumino R, Ricceri F, Quiros JR, Travier N, Sanchez MJ, Navarro C, Ardanaz E, Amiano P, Bueno-deMesquita HB, van Duijnhoven F, Monninkhof E, May AM, Khaw KT, Wareham N, Key TJ, Travis RC, Borch KB, Sund M, Andersson A, Fedirko V, Rinaldi S, Romieu I, Wahrendorf J, Riboli E, Kaaks R. Physical activity and risk of breast cancer overall and by hormone receptor status: The European prospective investigation into cancer and nutrition. International Journal of Cancer. 2013; 132(7):1667-1678.10.1002/ijc.27778 
33. Mertens A, Sweeney C, Shahar E, Rosamond W, Folsom Aaron R. Physical activity and breast cancer incidence in middle-aged women: a prospective cohort study. Breast Cancer Research and Treatment. 2006; 97(2):209-214.10.1007/s10549-005-9114-7 [PubMed: 16322883]

34. Dorgan JF, Brown C, Barrett M, Splansky GL, Kreger BE, D'Agostino RB, Albanes D, Schatzkin A. Physical Activity and Risk of Breast Cancer in the Framingham Heart Study. American Journal of Epidemiology. 1994; 139(7):662-669. [PubMed: 8166127]

35. Moradi T, Adami HO, Bergstrom R, Gridley G, Wolk A, Gerhardsson M, Dosemeci M, Nyren O. Occupational physical activity and risk for breast cancer in a nationwide cohort study in Sweden. Cancer Causes \& Control. 1999; 10(5):423-430.10.1023/a:1008922205665 [PubMed: 10530613]

36. Lahmann PH, Friedenreich C, Schuit AJ, Salvini S, Allen NE, Key TJ, Khaw KT, Bingham S, Peeters PHM, Monninkhof E, Bueno-De-Mesquita HB, Wirfaelt E, Manjer J, Gonzales CA, Ardanaz E, Amiano P, Quiros JR, Navarro C, Martinez C, Berrino F, Palli D, Tumino R, Panico S, Vineis P, Trichopoulou A, Bamia C, Trichopoulos D, Boeing H, Schulz M, Linseisen J, ChangClaude J, Chapelon FC, Fournier A, Boutron-Ruault MC, Tjonneland A, Johnson NF, Overvad K, Kaaks R, Riboli E. Physical activity and breast cancer risk: The European prospective investigation into cancer and nutrition. Cancer Epidemiology Biomarkers \& Prevention. 2007; 16(1):36-42.10.1158/1055-9965.epi-06-0582

37. George SM, Irwin ML, Matthews CE, Mayne ST, Gail MH, Moore SC, Albanes D, BallardBarbash R, Hollenbeck AR, Schatzkin A, Leitzmann MF. Beyond Recreational Physical Activity: Examining Occupational and Household Activity, Transportation Activity, and Sedentary Behavior in Relation to Postmenopausal Breast Cancer Risk. American Journal of Public Health. 2010; 100(11):2288-2295.10.2105/ajph.2009.180828 [PubMed: 20864719]

38. Weng HY, Hsueh YH, Messam LLM, Hertz-Picciotto I. Methods of Covariate Selection: Directed Acyclic Graphs and the Change-in-Estimate Procedure. American Journal of Epidemiology. 2009; 169(10):1182-1190.10.1093/aje/kwp035 [PubMed: 19363102]

39. Ainsworth, BE. The Compendium of Physical Activities Tracking Guide. Prevention Research Center, Norman J Arnold School of Public Health, University of South Carolina; 2002.

40. Friedenreich CM, Cust AE. Physical activity and breast cancer risk: impact of timing, type and dose of activity and population subgroup effects. British Journal of Sports Medicine. 2008; 42(8): 636-647.10.1136/bjsm.2006.029132 [PubMed: 18487249]

41. Pronk A, Ji BT, Shu XO, Chow WH, Xue S, Yang G, Li HL, Rothman N, Gao YT, Zheng W, Matthews CE. Physical activity and breast cancer risk in Chinese women. Br J Cancer. 2011; 105(9):1443-1450. [PubMed: 21934685]

42. Rintala PE, Pukkala E, Paakkulainen HT, Vihko VJ. Self-experienced physical workload and risk of breast cancer. Scandinavian Journal of Work Environment \& Health. 2002; 28(3):158-162.

43. Thune I, Brenn T, Lunk E, Gaard M. Physical activity and the risk of breast cancer. New England Journal of Medicine. 1997; 336(18):1269-1275.10.1056/nejm199705013361801 [PubMed: 9113929]

44. Steindorf K, Ritte R, Tjonneland A, Johnsen NF, Overvad K, Ostergaard JN, Clavel-Chapelon F, Fournier A, Dossus L, Lukanova A, Chang-Claude J, Boeing H, Wientzek A, Trichopoulou A, Karapetyan T, Trichopoulos D, Masala G, Krogh V, Mattiello A, Tumino R, Polidoro S, Ramon Quiros J, Travier N, Sanchez MJ, Navarro C, Ardanaz E, Amiano P, Bueno-de-Mesguita HB, van Duijnhoven FJB, Monninkhof E, May AM, Khaw KT, Wareham N, Key TJ, Travis RC, Borch KB, Fedirko V, Rinaldi S, Romieu I, Wark PA, Norat T, Riboli E, Kaaks R. Prospective Study on Physical Activity and Risk of In Situ Breast Cancer. Cancer Epidemiology Biomarkers \& Prevention. 2012; 21(12):2209-2219.10.1158/1055-9965.epi-12-0961

45. Gammon MD, John M, Britton JA. Recreational and occupational physical activities and risk of breast cancer. Journal of the National Cancer Institute. 1998; 90(2):100-117.10.1093/jnci/90.2.100 [PubMed: 9450570]

46. Loprinzi PD, Cardinal BJ, Smit E, Winters-Stone KM. Physical activity and breast cancer risk. Journal of Exercise Science \& Fitness. 2012; 10(1):1-7.10.1016/j.jesf.2012.04.004

47. Potischman N, Swanson CA, Siiteri P, Hoover RN. Reversal of Relation Between Body Mass and Endogenous Estrogen Concentrations With Menopausal Status. Journal of the National Cancer Institute. 1996; 88(11):756-758.10.1093/jnci/88.11.756 [PubMed: 8637031] 
48. Hankinson SE, Willett WC, Manson JE, Colditz GA, Hunter DJ, Spiegelman D, Barbieri RL, Speizer FE. Plasma Sex Steroid Hormone Levels and Risk of Breast Cancer in Postmenopausal Women. Journal of the National Cancer Institute. 1998; 90(17):1292-1299.10.1093/jnci/ 90.17.1292 [PubMed: 9731736]

49. Rinaldi S, Key TJ, Peeters PHM, Lahmann PH, Lukanova A, Dossus L, Biessy C, Vineis P, Sacerdote C, Berrino F, Panico S, Tumino R, Palli D, Nagel G, Linseisen J, Boeing H, Roddam A, Bingham S, Khaw KT, Chloptios J, Trichopoulou A, Trichopoulos D, Tehard B, Clavel-Chapelon F, Gonzalez CA, Larrañaga N, Barricarte A, Quirós JR, Chirlaque MD, Martinez C, Monninkhof E, Grobbee DE, Bueno-de-Mesquita HB, Ferrari P, Slimani N, Riboli E, Kaaks R. Anthropometric measures, endogenous sex steroids and breast cancer risk in postmenopausal women: A study within the EPIC cohort. International Journal of Cancer. 2006; 118(11):2832-2839.10.1002/ijc. 21730

50. Key TJ, Appleby PN, Reeves GK, Roddam A, Dorgan JF, Longcope C, Stanczyk FZ, Stephenson HE Jr, Falk RT, Miller R, Schatzkin A, Allen DS, Fentiman IS, Wang DY, Dowsett M, Thomas HV, Hankinson SE, Toniolo P, Akhmedkhanov A, Koenig K, Shore RE, Zeleniuch-Jacquotte A, Berrino F, Muti P, Micheli A, Krogh V, Sieri S, Pala V, Venturelli E, Secreto G, Barrett-Connor E, Laughlin GA, Kabuto M, Akiba S, Stevens RG, Neriishi K, Land CE, Cauley JA, Kuller LH, Cummings SR, Helzlsouer KJ, Alberg AJ, Bush TL, Comstock GW, Gordon GB, Miller SR. Body mass index, serum sex hormones, and breast cancer risk in postmenopausal women. J Natl Cancer Inst. 2003; 95(16):1218-1226. [PubMed: 12928347]

51. Evenson KR, McGinn AP. Test-Retest Reliability of Adult Surveillance Measures for Physical Activity and Inactivity. American Journal of Preventive Medicine. 2005; 28(5):470-478. doi: http://dx.doi.org/10.1016/j.amepre.2005.02.005. [PubMed: 15894151]

52. Wareham NJ, Jakes RW, Rennie KL, Schuit J, Mitchell J, Hennings S, Day NE. Validity and repeatability of a simple index derived from the short physical activity questionnaire used in the European Prospective Investigation into Cancer and Nutrition (EPIC) study. Public Health Nutrition. 2003; 6(04):407-413.10.1079/PHN2002439 [PubMed: 12795830] 
Table 1

Characteristics of the study population by lifetime occupational physical activity

\begin{tabular}{|c|c|c|c|}
\hline & & $\begin{array}{c}\text { Never Active } \\
\text { N=33,551 (74\%) } \\
\text { No. }(\%)\end{array}$ & $\begin{array}{c}\text { Ever Active } \\
\text { N=11,822 }(26 \%) \\
\text { No. }(\%)\end{array}$ \\
\hline \multirow[t]{4}{*}{ Age at interview } & $60+$ years & $11,337(34)$ & $3,095(26)$ \\
\hline & $55-59$ years & $6,718(20)$ & $2,356(20)$ \\
\hline & $50-54$ years & $6,309(19)$ & $2,604(22)$ \\
\hline & $<50$ years & $9,187(27)$ & $3,767(32)$ \\
\hline \multirow[t]{4}{*}{ Race/Ethnicity } & Non-Hispanic White & $28,002(83)$ & $9,797(83)$ \\
\hline & Non-Hispanic Black & $3,097(9)$ & $1,039(9)$ \\
\hline & Hispanic & $1,603(5)$ & $651(6)$ \\
\hline & Other & $849(3)$ & $336(3)$ \\
\hline \multirow[t]{4}{*}{ Education at interview } & College/Post Grad & $22,410(67)$ & $7,384(62)$ \\
\hline & Some College & $6,376(19)$ & $2,372(20)$ \\
\hline & High School Grad/GED & 4,477 (13) & $1,848(16)$ \\
\hline & $<$ High School Grad & $288(1)$ & $218(2)$ \\
\hline \multirow[t]{3}{*}{ Household income at interview } & $\$ 100,000+/$ year & $12,004(36)$ & $3,359(28)$ \\
\hline & $\$ 50,000-<\$ 100,000 /$ year & $13,682(41)$ & $4,809(41)$ \\
\hline & $\$<50,000 /$ year & $7,865(23)$ & $3,654(31)$ \\
\hline \multirow[t]{4}{*}{ Parity } & $3+$ births & $9,913(30)$ & $3,777(32)$ \\
\hline & 2 births & $12,653(38)$ & $4,160(35)$ \\
\hline & 1 birth & $4,901(15)$ & $1,712(14)$ \\
\hline & nulliparous & $6,084(18)$ & $2,173(18)$ \\
\hline \multirow[t]{2}{*}{ Menopausal status } & premenopausal & $11,731(35)$ & $4,710(40)$ \\
\hline & postmenopausal & $21,820(65)$ & $7,112(60)$ \\
\hline \multirow[t]{4}{*}{ Age at menopause ${ }^{*}$} & $55+$ years & 2,487 (13) & 707 (12) \\
\hline & $50-54$ years & $7,650(41)$ & $2,174(36)$ \\
\hline & $45-49$ years & $4,763(25)$ & $1,636(27)$ \\
\hline & $<45$ years & $3,801(20)$ & $1,572(26)$ \\
\hline \multirow[t]{3}{*}{ Body mass index at interview } & 230 & $9,942(29)$ & $3,866(33)$ \\
\hline & $25-30$ & $10,619(32)$ & $3,771(32)$ \\
\hline & $<25$ & $12,990(39)$ & $4,185(35)$ \\
\hline \multirow[t]{4}{*}{ Recreational activity } & Q4 (67.16+ MET-hr/wk) & $7,453(22)$ & $3,889(33)$ \\
\hline & Q3 (44.40 - <67.16 ME T -hr/wk) & $8,257(25)$ & $3,103(26)$ \\
\hline & Q2 (27.05 - <44.40 ME T -hr/wk) & $8,832(26)$ & $2,506(21)$ \\
\hline & Q1 (<27.05 ME T -hr/wk) & $9,009(27)$ & $2,324(20)$ \\
\hline \multirow[t]{2}{*}{ Work at night } & Ever & $7,481(22)$ & $5,972(51)$ \\
\hline & Never & $26,070(78)$ & $5,850(49)$ \\
\hline
\end{tabular}

* Postmenopausal women only. 


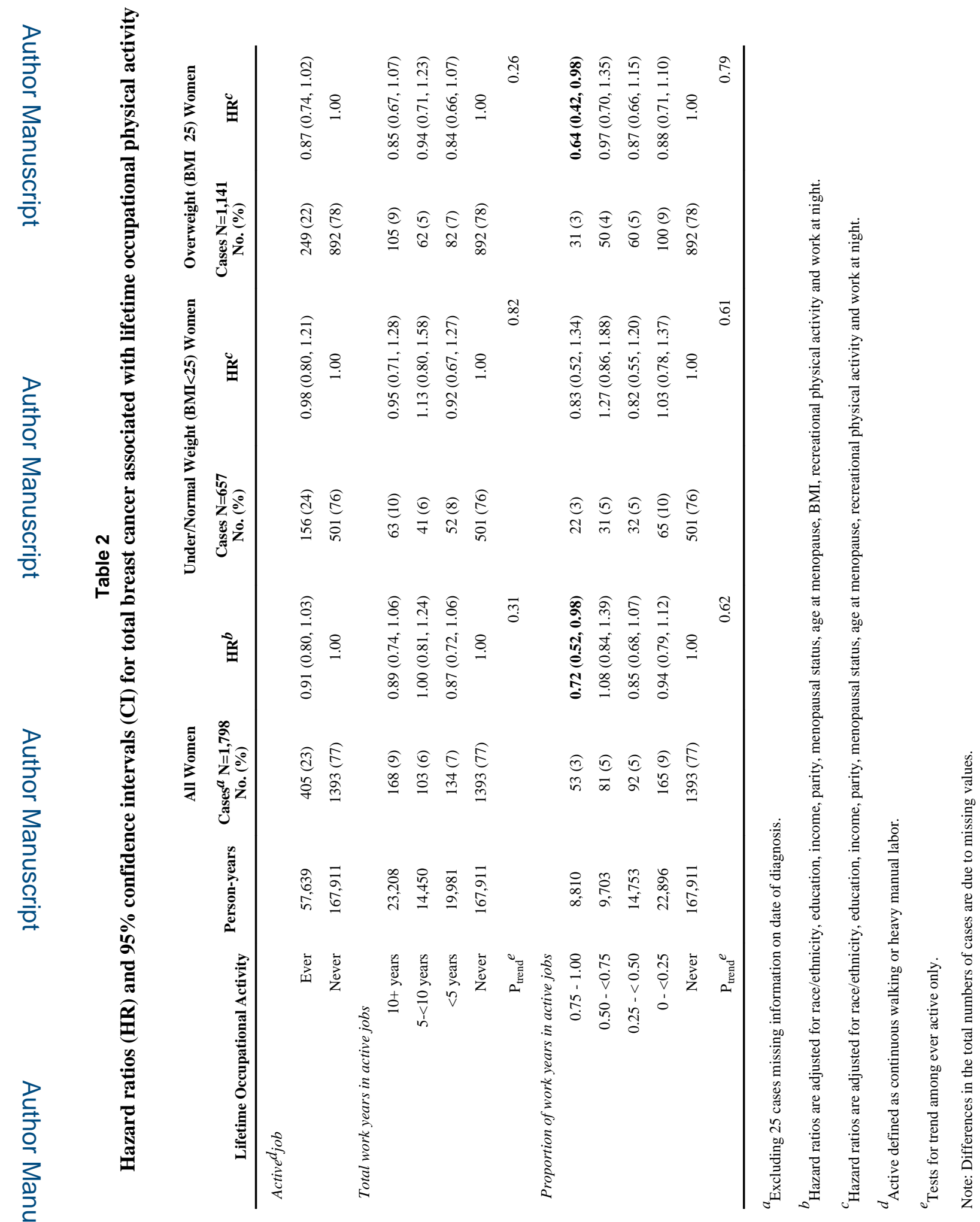




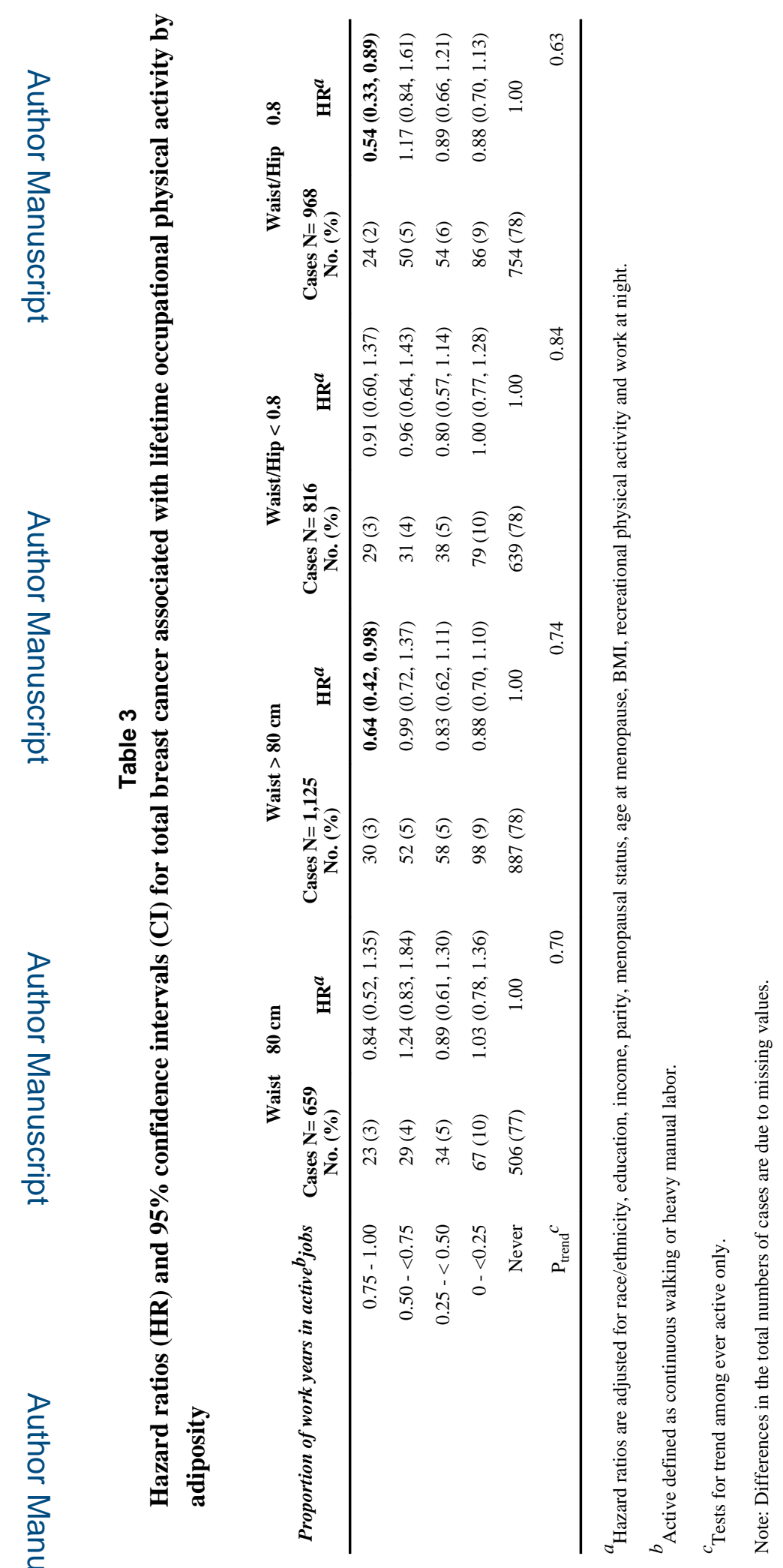


Table 4

Hazard ratios (HR) and $95 \%$ confidence intervals (CI) for breast cancer by menopausal status

\begin{tabular}{|c|c|c|c|c|}
\hline \multirow[b]{2}{*}{ Occupational Physical Activity } & \multicolumn{2}{|c|}{ Premenopausal } & \multicolumn{2}{|c|}{ Postmenopausal } \\
\hline & $\begin{array}{c}\text { Cases } \mathrm{N}=422 \\
\text { No. }(\%)\end{array}$ & $\mathrm{HR}^{a}$ & $\begin{array}{c}\text { Cases } N=1363 \\
\text { No. }(\%)\end{array}$ & $\mathrm{HR}^{b}$ \\
\hline \multicolumn{5}{|l|}{ Active ${ }^{C}$ job } \\
\hline Ever & $125(30)$ & $1.06(0.84,1.33)$ & $279(20)$ & $0.86(0.74,1.00)$ \\
\hline Never & $297(70)$ & 1.00 & $1,084(80)$ & 1.00 \\
\hline \multicolumn{5}{|l|}{ Total work years in active jobs } \\
\hline $10+$ years & $42(10)$ & $1.01(0.71,1.44)$ & $125(9)$ & $0.85(0.68,1.05)$ \\
\hline $5-<10$ years & $38(9)$ & $1.25(0.89,1.77)$ & $65(5)$ & $0.89(0.68,1.17)$ \\
\hline$<5$ years & $45(11)$ & $1.00(0.69,1.35)$ & $89(7)$ & $0.85(0.67,1.08)$ \\
\hline Never & $297(70)$ & 1.00 & $1,084(80)$ & 1.00 \\
\hline $\mathrm{P}_{\text {trend }} d$ & & 0.12 & & 0.34 \\
\hline \multicolumn{5}{|l|}{ Proportion of work years in active jobs } \\
\hline $0.75-1.00$ & $16(4)$ & $0.84(0.48,1.47)$ & $37(3)$ & $0.67(0.45,0.98)$ \\
\hline $0.50-<0.75$ & $22(5)$ & $1.14(0.73,1.79)$ & $59(4)$ & $1.09(0.81,1.47)$ \\
\hline $0.25-<0.50$ & $33(8)$ & $1.10(0.76,1.60)$ & $59(4)$ & $0.73(0.55,1.00)$ \\
\hline $0-<0.25$ & $48(11)$ & $1.01(0.74,1.41)$ & $117(9)$ & $0.93(0.75,1.14)$ \\
\hline Never & $297(70)$ & 1.00 & $1,084(80)$ & 1.00 \\
\hline $\mathrm{P}_{\text {trend }} d$ & & 0.81 & & 0.73 \\
\hline
\end{tabular}

${ }^{a}$ Hazard ratios are adjusted for race/ethnicity, education, income, parity, BMI, recreational physical activity and work at night.

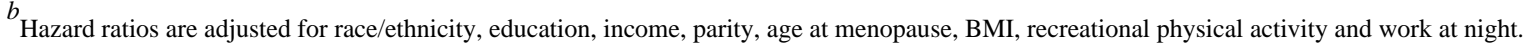

${ }^{c}$ Active defined as continuous walking or heavy manual labor.

$d_{\text {Tests for trend among ever active only. }}$

Note: Differences in the total numbers of cases are due to missing values. 
Table 5

Hazard ratios (HR) and 95\% confidence intervals (CI) for breast cancer by estrogen receptor status

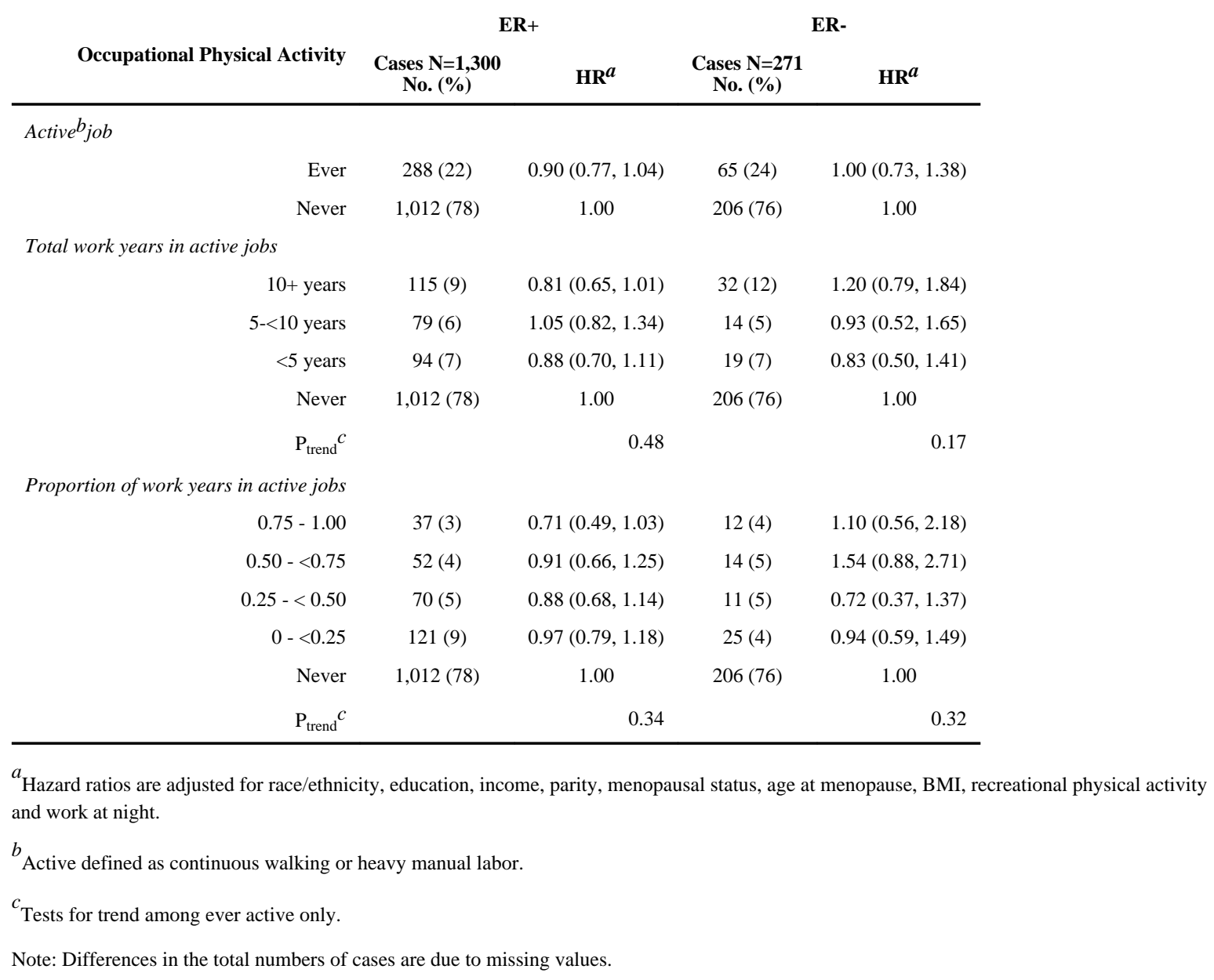


Table 6

Hazard ratios (HR) and $95 \%$ confidence intervals (CI) for total breast cancer associated with intensity of occupational physical activity (current workers at baseline $n=31,289$ )

\begin{tabular}{|c|c|c|}
\hline Intensity & $\begin{array}{c}\text { Cases } N=1,125 \\
\text { No. }(\%)\end{array}$ & $\mathrm{HR}^{a}$ \\
\hline \multicolumn{3}{|l|}{ Longest held job } \\
\hline Active $^{b}$ & $103(9)$ & $0.84(0.66,1.08)$ \\
\hline Mostly standing & $201(18)$ & $0.96(0.80,1.15)$ \\
\hline Sitting and standing equally & $264(23)$ & $1.05(0.89,1.23)$ \\
\hline Mostly sitting & $557(50)$ & 1.00 \\
\hline$P_{\text {trend }}$ & & 0.74 \\
\hline \multicolumn{3}{|l|}{ Current job } \\
\hline Active $^{b}$ & $81(7)$ & $0.75(0.58,0.96)$ \\
\hline Mostly standing & $185(16)$ & $0.93(0.78,1.11)$ \\
\hline Sitting and standing equally & $231(20)$ & $0.87(0.74,1.02)$ \\
\hline Mostly sitting & $633(56)$ & 1.00 \\
\hline $\mathrm{P}_{\text {trend }}$ & & 0.18 \\
\hline
\end{tabular}

${ }^{a}$ Hazard ratios are adjusted for race/ethnicity, education, income, parity, menopausal status, age at menopause, BMI, recreational physical activity, total number of work years, and work at night.

${ }^{b}$ Active defined as continuous walking or heavy manual labor.

Note: Differences in the total numbers of cases are due to missing values. 